\title{
Learning Language, Learning Culture: Constructing Finnishness in Adult Learner Textbooks
}

Titus Hjelm, Riitta-Liisa Valijärvi, Alessia Lee, Alina Linnenweber, Tímea Tárkányi \& Jo Troll

Finland, like most European countries, is going through a period soul-searching unprecedented in the $21^{\text {st }}$ century. Nationalist populism, with its claim to a somehow authentic Finnishness has been a serious political force from the beginning of the second decade, prompting regular and fierce debates about national identity. The original English name of the populist Perussuomalaiset party, 'True Finns', is only a more explicit version of their current name, 'The Finns'. The refugee crisis of 2015 has only exacerbated the situation by hardening the public discourse, with participants from random Facebook commentators to sitting MPs flirting with openly racist language, and making 'debate' a generous term for the cacophony of insult and intellectual entrenchment.

While 'identity' as a concept is a new invention, and a reflection of the times of its production (Moran, 2015), it is sensible to argue that for modern Finns and Europeans, the issue of national identity is indeed increasingly an 'inescapable' part of everyday life (Poole, 2003). It is not, however, inescapable because it is somehow transmitted in mother's milk. On the contrary, it is in times of controversy when unquestioned, common sense assumptions about national identity become articulated, negotiated, and challenged. Riffing on Marx, philosophers Alcoff and Mendieta $(2003,3)$ argue that 'Identity is not in the main an individual affair. Individuals make their own identity, but not under conditions of their own choosing'. We agree, but also emphasise that the conditions in which national identity is constructed are not monolithic, but rather in constant motion. Again, national identity becomes 'inescapable' only in conditions which demand an articulation of it- 
conditions in which Finland and other European countries currently find themselves (see Mole, 2007b).

The key issue since the rise of the populist right, and especially since the refugee crisis, is the commonplace claim that the immigrants and refugees are incapable of integrating into Finnish society and culture. The mainstream anti-immigration discourse tries to avoid accusations of racism by directing the blame to incompatible culture and, especially, Islam. Although seemingly more sophisticated, these claims see 'culture' no less essentially than openly racist commentary. The racialisation of immigrants in general, and Muslims in particular, is now part and parcel of Finnish public discourse on immigration (cf. e.g. Näre \& Nordberg, 2016; Keskinen, 2012; Virdee, Kyriakides \& Modood, 2006). What these type of claims miss completely is not only the constructedness of the immigrants' culture, but also that of Finnish culture. Hence, in order to understand the claims of incompatibility, we need to understand how 'Finnishness' is constructed.

While a corpus of work on the construction of Finnishness in academic, media and political discourse is emerging (e.g. Honko, 1996; Kauppi, 1996; Paasi, 1997; Anttila, 2007; Obertz-Siitonen \& Siitonen, 2015), we want to direct our gaze to the so far little studied but key issue of adult socialisation through Finnish language teaching materials. Learning a second language can be considered a primary example of what Berger and Luckmann call 'secondary socialisation', that is, learning the rules of language, but also the norms of language-use (Berger and Luckmann, 1967: 138; Hjelm, 2014: 23-25). Through careful decisions concerning what to include and what to omit, textbooks have the power to direct what a beginner can and should say in their target language. Additionally, textbooks have the responsibility of representing the cultures that speak the language. Much of a language learner's initial understanding of a national culture in its own language is dependent on the 
constructions of that culture in their learning resources (Kramsch, 1993; Risager \& Chapelle, 2012). While the explicit aim of foreign language textbooks is the transmission of grammar, vocabulary, and communication skills, they are also always vehicles of socialisation through the 'hidden curriculum' concerning norms and values (Bourdieu \& Passeron 1990; Giroux \& Penna, 1979; Gray, 2013a; CurdtChristiansen \& Weninger, 2015a). Speaking of history textbooks, Soysal and Schissler (2005:2) argue that 'as far as textbooks continue to be national narratives, they provide a key through which national and citizenship identities are projected and constructed vis-à-vis a wider world' (see also Bénéï 2005; 2008). Similarly, but with reference to language learning, Curdt-Christiansen and Weninger (2015a:3) argue that the study of textbooks can uncover 'the relationship between the social (re)construction of ethno-national identity and language policy'. Indeed, we follow Pavlenko and Lantof's (2000: 155) often-cited definition of second-language learning 'not as the acquisition of a new set of grammatical, lexical, and phonological forms, but as a struggle of concrete socially constituted and always situated beings to participate in the symbolically mediated lifeworld... of another culture'.

The aim of this article is to analyse how two widely used series of Finnish language textbooks for adult learners construct 'typical' Finnishness. Although we are methodologically restricted to the analysis of text, we will theoretically elaborate on how the textbooks construct 'worlds of possibility', that is, how they succeed or fail in constructing an inclusive view of Finnishness. These worlds of possibility can be said to have particular effects-although these are not predetermined by the texts themselves-depending on which types of agency the cultural constructions enable or constrain. Through an application of a version of critical discourse analysis, we show that the hegemonic image of Finnishness conforms to the stereotype of a modern, advanced, and natureloving people. But the image is also middle-class, white, and conventional (even conservative) in terms of gender equality and sexuality. We argue that textbooks can have a key role in constructing 
an inclusive sense of the host culture, and that this inclusiveness can be an asset for language acquisition, although at the moment they fall short of this aim.

While there is an established literature on stereotyping (e.g. Johnson, 1973) and, more recently, national identity and culture constructions in language textbooks (Sercu, 1998; Ulrich, 2004; Gray, 2013a; Curdt-Christiansen \& Weninger, 2015b), especially for English as a foreign language and other major European languages, there are few systematic analyses of the construction of Finnishness in Finnish language textbooks for adult learners. Tanner (2012) has focused on requests in dialogues in Finnish language textbooks aimed at non-native speakers and Vehkanen (2015) has studied the changing contents and contexts of Finnish as a foreign language textbooks published between 1866 and 1953. Neither of these, however, takes the more critical approach to representations of identity that we engage in. In that sense, Salmu's (2002) work on the representations of men and women in two Finnish as a foreign language textbooks, is the only one that comes closer to what we endeavour to do with our analysis. That said, we want to acknowledge that our analysis is a snapshot case study of learning material currently in use in Finland and abroad. Hence, we cannot and do not presume to make strong claims about whether and/or how the constructions of Finnishness reflect longitudinal changes in Finnish society and culture. However, since the first editions of the older textbooks were published more than 25 years earlier than the new textbooks, we do briefly reflect on the significance of the time difference in the conclusion.

We begin by describing our version of critical discourse analysis, our data, and the analytical scheme for analysis. The rest of the article is structured along the lines of this scheme, with the first two sections examining constructions of Finnishness in direct (someone in a text telling about Finnishness) and indirect (texts showing Finnishness in action) forms. Since Finland and the Nordic 
countries more broadly are known for their putative gender equality, we use gender as a case of presenting and representing Finnishness in the next two sections. Finally, we close with a discussion of the implications of the findings to broader debates about national identity and language learning, but also to current controversies regarding Finnish identity, citizenship, and culture.

\section{The Discursive Construction of National Identity: Presentation and Representation}

As explained above, we see national identity-like any type of identity-as a product of processes of social construction (Hjelm, 2014). Thus, despite the tendency to reify identity as something essential to an entity-in this case, 'the nation' - we see national identity articulated in acts of identification (cf. Brubaker and Cooper, 2000). These range from political discourse to media text and everyday talk. Our focus, of course, is on educational discourse. As Mole (2007a) and colleagues demonstrate, discourse analysis in its various forms is perfectly suited to examine these processes of identification. This is especially so because, as Hjelm $(2014,6)$ argues, of the 'action orientation' of discourse. That is, discourse analysis is not only interested in what is being said, but more importantly how things are done with discourse.

Ours is a loose application of critical discourse analysis (CDA), especially as formulated by Norman Fairclough (1992) and John E. Richardson (2007). CDA analyses the ideological functions of discourse, that is, 'constructions of reality (the physical world, social relations, social identities), which are built into various dimensions of the forms/meanings of discursive practices, and which contribute to the production, reproduction or transformation of relations of domination' (Fairclough, 1992: 87). CDA aims to uncover how (and why) particular ways of talking about things become dominant while suppressing alternative views, and what the potential consequences of these hegemonic discourses 
are. Ruth Wodak and her colleagues have applied a slightly different version of CDA to their work on discourse and national identity building (e.g. De Cillia, Reisigl \& Wodak 1999; Wodak \& Boukala 2015). While we acknowledge the relevance of that corpus of work, we have retained Fairclough's original model of CDA, partly because of the clear tools it offers for analysis (see below), and partly in order to facilitate commensurable team analysis.

In this article we prioritise the analysis of meaning over the analysis of form. Hence, our main methodological tool in the CDA 'toolkit' is the study of narrative, that is, how a story unfolds, and how narratives 'establish relationships between or among things (e.g. events, states, situations) over time' (Jasinski, 2001: 390, quoted in Richardson, 2007: 74). That said, we do include other aspects of the CDA toolkit (Richardson, 2007: 47) that pertain to the form of text when these are relevant for the understanding of the textbook discourse. These include an examination of lexis, or word choice, which is particularly important when word choice creates a sense of 'us' and 'them'. We also pay attention to transitivity, which is the key to understanding the representation of agency in discourse (Richardson, 2007: 57). In other words, we are interested in how grammatical construction affects who is portrayed as an active agent-someone who does things - and who as a passive agentsomeone to whom things happen. Finally, the study of modality is built into our analytical scheme summarised in Table 1. [1]

The rich textbook material offers various ways of organising the analysis. We could have structured our argument along a systematic review of the different aspects of the CDA toolkit, or we could have mapped different discourses (in the plural) about the variety of substantive ways in which Finnishness is constructed. However, we took the idea of modality (in a broad sense), that is, the ways in which the 'speaker or writer is committed to the claim that he or she is making' (Richardson, 
2007: 59), and built our analytical scheme around it. This is presented in Table 1. On the top of the table we have differentiated between direct and indirect presentation, or the form the text takes when constructing Finnishness. Direct presentation refers to texts where the authors or the characters in the textbooks tell about Finnishness. This telling about Finnishness happens, for example, when a family is described as a 'typical/ordinary Finnish family' (see below; Gehring and Heinzmann, 2013b: 8). Indirect presentation in turn shows the reader Finnishness in action, when for example a group of young men go to the summer cottage for the weekend and do supposedly 'Finnish' things (see below; Gehring and Heinzmann, 2013b: 81-83). On the left side we make a distinction between the different ways in which Finnishness is constructed in the content of the text. We call this representation in distinction from presentation (form). Under direct representation we have included cases where the textbooks (authors or characters) explicitly talk about Finnishness, and cases where 'typical' Finnish actions are shown. In our scheme indirect representation can be analysed by taking a sociological category (class, gender, sexuality, religion, etc.) and using it as a heuristic lens through which to examine how representations of those categories construct Finnishness. For our study, we have chosen the case of gender, that is, how gender representations in the textbooks construct what is considered part of national identity. The choice of gender is justified in light of the widely adopted discourse about gender equality in the Nordic countries, and in Finland in particular (Marakowitz 1996). The reality of this discourse has been rightly called into question, but the undisputed fact is that Finland and the other Nordic countries are often perceived as 'paradises for women' (Holli, Magnusson \& Rönnblom, 2005: 148). This makes analysing gender socialisation through material targeted at adults from other cultures especially interesting. As above, we've made a distinction between telling about gender and showing gender roles in action.

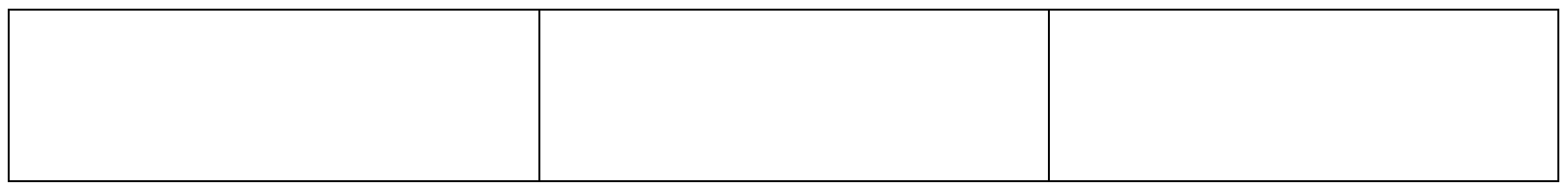




\begin{tabular}{|c|c|c|}
\hline & DIRECT PRESENTATION & INDIRECT PRESENTATION \\
\hline DIRECT REPRESENTATION & Telling about Finnishness & Showing Finnishness \\
\hline INDIRECT REPRESENTATION & Telling about gender in Finland & Showing gender in Finland \\
\hline
\end{tabular}

Table 1: The Analytical Scheme

The analytically most problematic piece of the scheme is 'showing Finnishness', because it is impossible to separate somehow purely 'cultural' constructions of Finnishness that would be independent of sociological categories. Obviously, most cases of direct representation have little to do with, say, the indirect category of religion. The issue gets more complicated, however, with a category such as gender, which arguably could be read into most examples of national identity construction (even, or perhaps exactly, when it is absent). Indeed, that box in the scheme could in itself be the object of the kind of mapping analysis mentioned above. Thus, when we say we are analysing these four aspects of the textbook discourse, we claim comprehensive coverage only in the other three, and include examples of 'showing Finnishness' as a selective point of comparison with the other types. 
Our data consists of five textbooks for adult learners that are currently in use in Finland and abroad: The older pair, the beginners' Suomen kielen alkeisoppikirja (Lepäsmaa and Silfverberg, 2010) and the more advanced Suomen kielen jatko-oppikirja (Silfverberg, 2003), originally published in 1987 and 1989 , respectively, are currently in the $12^{\text {th }}$ and $6^{\text {th }}$ editions. The newer series, Suomen mestari, consists of three books for the beginner, lower intermediate, and upper intermediate level student (Gehring and Heinzmann, 2013a; Gehring and Heinzmann, 2013b; Gehring et al., 2013). Both series of textbooks are written in Finnish only. The older series guides the reader efficiently through Finnish core grammar and basic vocabulary but contains no colours and few communicative or listening exercises. The newer series is colourful and communicative and accompanied by listening and writing exercises, games and puzzles, and photos. The two series were chosen from a number of textbooks and other study material (23 comparable individual books for different levels of language proficiency; Opetushallitus, 2011: 23-31), because to our knowledge these books are most widely used in Finnish language classes that learners such as migrants and university students take (e.g. at University of Helsinki Language Centre and evening classes). As such they provide an important window into what the construction of Finland and Finnishness looks like for the adult foreign language learner at this point in time.

Practically speaking, the source material was split between the team, each member individually looking for text examples relevant to the analytical scheme presented above. The extracts presented below are hence an outcome of a sort of purposive sampling, as the point of analysis was not to demonstrate frequencies, but rather the quality of the discourse under each category of the analytical scheme. After individual analysis, the examples and interpretation were discussed and corroborated as a team - a technique suggested by Nikander (2008) as the equivalent of reliability and validity tests in discursive research. 


\section{Telling about Finnishness}

In our analytical scheme telling about Finnishness refers to the ways in which the authors, either directly in the form of narrative, or through the mouths of the characters in the books, explain what Finnishness consists of. A prime example is the introduction to the characters in Suomen mestari 2 (Gehring and Heinzmann, 2013b: 8): The Mäkelä family is described as 'a typical/ordinary Finnish family' ('Mäkelät ovat tavallinen suomalainen perhe'). They are a married couple, both working, with two children, a boy and a girl. While a staple image of the western nuclear family, it presupposes multiple sociologically significant issues regarding 'ordinariness' in Finnish society and culture: heterosexuality, middle class social status (the father is an architect and the mother works in a bank part-time), and marriage as the norm of family life. Almost needless to say, the Mäkeläs are white, 'ethnic' Finns. The last point is significant especially in light of the other main characters in the Suomen mestari series being recent migrants (an apparently mixed race Brazilian, a white Russian, and a white South African). The depiction of family life in Suomen kielen alkeisoppikirja echoes that of Suomen mestari: 'Kari Palonen is an ordinary Finnish man'. [...] Kari Palonen also has a family: a wife, three children and a dog. ('Kari Palonen on tavallinen suomalainen mies. [...] Kari Palosella on myös perhe: vaimo, kolme lasta ja koira.' Lepäsmaa \& Silfverberg, 2010: 90).

In Suomen mestari 2, there is an interview with Alex, the South-African, in which he is asked about what he liked about living in Finland. He explains: 'I enjoyed Finland very much and fell in love especially with Finnish nature: the lakes, forests, and the different seasons. I also liked Finnish people, because they are so calm/quiet and reliable' ('Viihdyin Suomessa tosi hyvin ja ihastuin erityisesti suomalaiseen luontoon: järviin, metsiin ja eri vuodenaikoihin. Pidin myös suomalaisista ihmisistä, koska he ovat niin rauhallisia ja luotettavia') (Gehring and Heinzmann, 2013:211). Also in 
an anonymous conversation example in Suomen kielen alkeisoppikirja Finns are said to be quiet (Lepäsmaa and Silfverberg, 2010:195):

- What do you think of the Finns?

- Yes, I think they are rather quiet.

- Sure, if you compare them to Italians.

- Well, even compared to Swedes or Russians. Swedes and Russians are sociable and talkative.

- Yes but [sic], Finns are different too. For example the Karelians are quite talkative.

- Yes. That is true and surely there is a difference between urban and rural people.

- $\quad$ (Mitä sinä ajattelet suomalaisista?

- Kyllä, he ovat minusta aika hiljaisia.

- Varmasti, jos vaikka vertaa italialaisiin.

- No, vaikka vertaisi ruotsalaisiin tai venäläisiin. Ruotsalaiset ja venäläiset ovat seurallisia ja puheliaita.

- Niin mutta, suomalaisetkin ovat erilaisia. Esimerkiksi karjalaiset ovat aika puheliaita.

- Niin. Onhan se niinkin ja varmaan on myös ero kaupunkilaisten ja maalaisten välillä).

The picture is more nuanced, as the book acknowledges the fact that there are differences between Finns: Karelians are talkative, and city-dwellers and people from the countryside are different in this respect. In fact, Suomen kielen jatko-oppikirja says that 'today's Finn is more or less a city-dweller now' ('tämän päivän suomalainen alkaa jo olla kaupunkilainen') (Silfverberg, 2005:119). Finland has changed with global music and fashion trends, and young people now sit in cafés socialising and even talking to strangers, which used to be rare in Helsinki (Silfverberg, 2005:120). 
Identity construction is not, however, only a matter of positive identification. The construction of 'the other'-negative identification-also functions to reinforce what is considered, in our case, typically Finnish. In Kai T. Erikson's insightful words, 'one of the surest ways to confirm an identity, for communities as well as for individuals, is to find some way of measuring what one is not' (Erikson, 1966: 64; emphasis in the original; Hjelm, 2014, 53). The same sentiment is echoed by Ulrich (2004: 166), with a special reference to foreign language textbooks: 'it is important to note that the portrayal of others is inextricably linked to the way nations/cultures perceive and understand their own identity'. This is exemplified by a chapter in Suomen mestari 3 with a telling title, Kummallista, which could mean 'odd', 'strange' or 'peculiar' (Gehring et al., 2013: 181). The opening dialogue of the chapter is between the Brazilian migrant Pedro and his Finnish neighbour Tuula Mäkelä, where she asks him: 'what did you think was strangest about Finland when you moved here?' By concentrating on what Pedro, the stranger, finds strange about Finland, the text performs a double negation which positively reinforces a particular image of Finnishness. It turns out that Pedro finds that his Finnish neighbours are anti-social and overly reserved. The text thus juxtaposes non-confrontational Finns with the perhaps more gregarious foreigners from countries further south. Tuula is sympathetic but provides a contrast in opinion to this behaviour from her own perspective, interpreting it as more a demonstration of politeness: 'We sometimes find it more polite to leave people in peace'. It is insinuated that Finnish people can acknowledge their own quirks (and constructed stereotypes) lightheartedly, reflecting positively on these qualities that set them apart from other cultures. Either way, the myth of the silent Finn (Olbertz-Siitonen and Siitonen, 2015) is reproduced through the characters telling about Finnishness in adult language textbooks.

\section{Showing Finnishness}


As suggested in the above discussion on methodology, 'showing Finnishness' is the most problematic category of the analytical scheme. It is almost always mixed with one or more of the indirect forms of representation. Hence, we will choose representative examples rather than try to typologise all accounts in the sources that could be included under this heading. One example of this kind of direct showing of Finnish identity is in a chapter titled 'Saving energy and recycling' ('Säästetään energiaa ja kierrätetään') in Suomen mestari 3. The chapter suggests that Finns have significant ecological consciences and are therefore an innovative nation and an advocate of a global agenda. Within the chapter there is one text of notable interest entitled 'Let's recycle' ('Kierrätetään!'), which involves a dialogue between Diego (who we are told has recently moved into a shared student apartment) and Siiri (his new flatmate), where he asks her for help to demystify their recycling system as he is puzzled by the assortment of bins (Gehring et al., 2013: 13). While Siiri does not at any point explicitly say that this is a particularly Finnish practice (as she would if the case was about direct presentation), the Finnishness of the practice is shown in contrast to what is represented as the norm for Diego. It is interesting that any further information about Diego is omitted, besides his name and the fact that he finds recycling a tricky concept to grasp. It can be inferred that Diego is a typically Hispanic name and even though he speaks good Finnish, he finds recycling, which has so far in the textbook been presented as a standard system for discarding waste in Finland, alien and puzzling.

Again, as with the case of constructing Finnishness through telling the experiences of the stranger (Pedro's story above), showing how recycling is part of everyday life in Finland becomes a double negative construction of Finnishness: That it is strange for a stranger naturalises recycling as part of Finnishness. The ecological theme is subtly reiterated in the accompanying exercises in a timetable for an all-day interactive fashion event entitled 'Winds of Fashion' ('muodin tuulet'), where a workshop is titled as 'let's make a hat from an old jumper!' ('Tehdään pipo vanhasta villapaidasta!'), 
presenting a penchant for conserving resources and a tendency to naturalise recycled fashion in the Finnish context.

In Suomen mestari 2, in the chapter titled 'Cottage trip' ('Mökkireissu'), South African Alex accompanies three Finnish work colleagues and friends-all men - to one of their summer cottages (or mökki) (Gehring and Heinzmann, 2013: 81-84). After a three-hour car journey the four of them spend the weekend there. They have a barbecue, go to the sauna, repair outside stairs, fell some trees, go fishing and eat the fish they catch. All of these activities are based around nature. The men are self-sustained, catching their own food and taking care of the cottage, and adept at living without today's technology and conveniences, like their ancestors did. With the topic of sauna, as seen on the illustrations on the page, nudity is also displayed as natural. The readers get the impression of a close connection to nature. The same connection to nature and the outdoors is evident also in Suomen kielen alkeisoppikirja despite the generally more urban outlook of the older series. In the autumn Finns go to the forest to pick berries and mushrooms. In the winter people ski and go ice skating (Lepäsmaa and Silfverberg, 2010: 92).

In Suomen kielen jatko-oppikirja, constructions of Finland are often established through biographies of male writers and their works, but whenever characters in a dialogue are considering attending a cultural event, the play or film is usually by a non-Finnish writer, as exemplified by the short text 'Teatterissa', in which the Helsinki City Theatre is showing works by playwrights such as Sartre, Molière, and Shakespeare (Silfverberg, 2010: 70). The same applies to Suomen kielen alkeisoppikirja where nameless people in a dialogue buy tickets to Rigoletto (Lepäsmaa and Silfverberg, 2010:213). This creates a tension between pride in Finnish work and a need to demonstrate that Finns are part of the global community and know the internationally accepted classics. 
Towards the end of Suomen kielen jatko-oppikirja, dialogues turn towards citizenship and political involvement, such as the dialogue 'Kansanedustaja', in which the characters discuss how to obtain records of what happens in a parliament session (Silfverberg, 2010: 62). Although the characters do not explicitly say that active political engagement is a particularly Finnish activity, the dialogue shows that this is indeed the presupposition (see Richardson 2007: 63-64). At the same time, its very late introduction in the book could suggest that only advanced Finnish speakers are welcome to engage in political activity, as Douglas Fleming proposes upon discovering the same pattern in English as a Second Language textbooks used in Canada (2010: 596).

Showing Finnishness through language and language capability is another recurring theme, especially in the advanced Suomen kielen jatko-oppikirja. In some of the dialogues, speaking Finnish is directly linked with cultural capital, if you will:

- There was an ad in the paper that the post office is looking for employees.

- Well, now you have a chance to get a job. You're applying, right?

- Of course, but how do I make the application? Should I perhaps write it in English so that it would be good?

- No, no. Write it in Finnish. They won't want you if you can't demonstrate that you can speak Finnish.

- But I always make mistakes.

- Sure, but it is still better that you at least try to write it in Finnish. That way they will get a more enterprising and honest picture of you.

- Well, maybe l'll do as you say. 
- $\quad$ (Lehdessä oli ilmoitus, että posti hakee uusia työntekijöitä.

- No, nythän sinulla on tilaisuus saada työpaikka. Kai sinä haet sitä?

- Totta kai, mutta miten minä teen sen hakemuksen? Pitäisiköhän minun kirjoittaa se englanniksi, että siitä tulisi hyvä?

- $\quad$ Ei, ei. Kirjoita se suomeksi. Eivät ne halua sinua, jos et osoita, että osaat suomea.

- Niin mutta kun minä teen aina virheitä.

- Joo, mutta kyllä silti on parempi, että edes yrität kirjoittaa suomeksi. Sillä tavalla ne saavat sinusta yritteliäämmän ja rehellisemmän kuvan.

- No, ehkä minä teen sitten, niin kuin sinä neuvot). (Silfverberg 2005:29)

Often telling about Finnishness is supplemented by showing it in action, sometimes literally, as in the case of Pedro finding Finns anti-social, discussed above. The dialogue between friendly neighbours, where the native Finn tells how Finns are, is reinforced by a somewhat dubious illustration, which shows half of Pedro's face peeping from a partially open door of a lift while a man in the corridor is passing by, looking back suspiciously and making for the stairs (Gehring et al. 2013: 181).

\section{Telling about Gender in Finland}

When language textbooks present scenes from life in the target culture, the action is by definition gendered. A critical discourse analysis of the ways in which textbooks (narrative or characters) explicitly talk about gender focuses on the transitivity of discourse, that is, how relationships between participants are constructed in these texts. Especially important is the masking or deletion of agency through passive sentence construction. When 'police shoot demonstrators' is changed into 'demonstrators are shot by the police', the focus of the sentence changes. Further, the actor 
can be deleted completely, as in 'demonstrators are shot' (Fairclough, 1992: 27; Richardson, 2007:

55). Equally important in the case of gender is the discursive technique of 'nominalization', where an active process is transformed into a 'state of affairs'. Thus saying 'capital is mobile' changes a transitive action ('companies move capital around the globe') into a state of affairs without agency (see Richardson, 2007: 56). So, what do the textbooks talk about when they talk about men and women-and these are indeed the binaries through which gender is constructed-in the Finnish context?

The first observation from the material is that there is very little talk about gender in the first place. Characters do not explicitly discuss gender or gender roles (as in: 'in Finland, men/women usually...'). It is rather in the narrations of events that we discern the roles men and women play. This is best shown in this paragraph from a brief text titled 'Boat Trip' (Veneretki) in Suomen kielen jatko-oppikirja:

The trip passed well, as it was. All duties were taken care of in cooperation. While the men looked after the boat and the steering, the women looked after the food. It rained a little on Saturday afternoon and we had to sit in the cabin waiting for the end of the rain. While we were waiting, we played chess. After the rain had cut off, we moved back to the deck to sunbathe.

(Retki sujui muutenkin hyvin. Kaikki toimet hoidettiin yhteistyössä. Miesten huolehtiessa veneestä ja ohjauksesta naiset huolehtivat ruoasta. Lauantai-iltapäivänä satoi hiukan ja meidän oli istuttava hytissä odottamassa sateen loppumista. Odottaessamme pelasimme šakkia. Sateen lakattua siirryimme taas kannelle ottamaan aurinkoa.) (Silfverberg, 2005:92). 
Here, the pairing of gendered and non-gendered subjects with verbs shows how action is gendered. Men do outside work and take care of transportation while women do what is considered housework, mainly cooking. However, playing chess and sunbathing are non-gendered activities. Overall, this suggests that work is gendered, while leisure activities are not. Importantly, the quote says 'all duties were taken care of in cooperation' (our emphasis). Yet, all duties were blatantly not taken care of in cooperation, naturalising the clearly gendered roles as common sense-which, according to Fairclough, is a prime example of the ideological functioning of texts (Fairclough, 1989: 84).

In another chapter of Suomen mestari 2, a family is vacationing in Turkey. The father and son go on a boat tour together, while mother and daughter decide to stay home and only leave for a short ice cream trip, but not for an adventure like the boys (Gehring and Heinzmann, 2013b:11-13). Not only are both genders literally separated here, but the two male characters once again take on a more active role through their actions. Furthermore, this piece of information is revealed during a dialogue between Tuula and Hanna - yet another example of women doing more talking than anything else.

\section{Showing Gender in Finland}

If the focus in analysing instances of telling about gender in Finland focused on the transitivity of discourse, or the form of talking about gender, looking at showing gender takes a broader view of agency. The focus is now less on how gender is talked about and more about who gets to speak in the first place (cf. Jones, Kitetu and Sunderland, 1997). As noted by many feminist scholars, it is often the naturalisation of the absence of women and their voice, which perpetuates male 
dominance in society. This is doubly interesting in a culture which, at least on the official level, likes to pride itself on achievements in gender equality.

There are visible differences between the roles female and male characters play in Suomen mestari 2. Looking at the overall narrative one can quite easily see that female characters are generally less active than the men. There are two texts with only female characters, both of which consist mostly of dialogue. One of them is a shopping trip made by Olga and a friend of hers in order to take care of family matters, such as buying clothes for her daughter and searching for a new coffee machine. The women are not only portrayed as doing a 'typical' female activity, namely shopping, but also as taking on the role of caretaker of the family. The men, on the other hand, merit more of the book and have three texts, two of which are almost solely narration of actions. One of these two is the aforementioned text about the men's trip to a summer cottage. The men are subject or agent of a great number of active verbs throughout the whole text. The dialogue is minimal but that makes the few lines spoken stand out all the more. One of them is uttered during the men's barbecue: 'Sausage is a Finnish man's vegetable' ('Makkara on suomalaisen miehen vihannes') (Gehring and Heinzmann, 2013b:82). Finnish men do things and do not eat vegetables.

Even when there are both men and women in the same text in Suomen mestari 2, there are noticeable differences between their roles. Although one of the chapters focuses on Hanna waking up ill and having to see a doctor, it is, interestingly, her boyfriend Pedro who is the most active person in the whole text: He takes care of her, checks her temperature and gets her everything she needs (Gehring and Heinzmann, 2013b: 49-50). The rest of the text is a dialogue between Hanna and the doctor, who is female in the recording. There is no doubt Pedro is taking on the role of the loving and caring boyfriend, but the text fits perfectly into the overall pattern of the book in which men tend to be more active, and women more passive. 
At first sight, it looks as if the main female character, Kaisa, in Suomen kielen alkeisoppikirja is an exception to the above pattern of agency. She is active and organised. She goes from work to the library and then to a concert (Lepäsmaa and Silfverberg, 2010: 43-44). She goes on a language course on her own (Lepäsmaa and Silfverberg, 2010: 106-107). She dances all night with her Italian boyfriend at a club (Lepäsmaa and Silfverberg, 2010: 122), and breaks a colleague's heart without even being aware of it while dancing with her boss (Lepäsmaa and Silfverberg, 2010: 132).

However, in the context of the whole material, Kaisa's case is somewhat of an outlier. Even the same text, the Suomen kielen alkeisoppikirja (Lepäsmaa and Silfverberg 2010:88), never strays far from rather classic roles, as for example when the readers are shown pictures with accompanying descriptions. In one 'photo' is the girl Riitta and her mother. They have a camera and a flower. Another picture shows Kaisa and her female friend Sabina. They have glasses and big earrings. Two other pictures are women with their pets. The pictures of men are quite different: Kari Palonen sits by a table with his family. The caption says 'This is Kari Palonen and the Palonen family. There are three children in the family'. The last picture is of a man next to his car. The caption says: 'This is engineer Nieminen. He does not have a family. Engineer Nieminen has a German car. The car has four doors'.

Even if Kaisa's active youth could be argued to challenge the rather stereotypical gender roles, women's agency almost disappears in the advanced text. In a text that compares two Finnish families in Suomen kielen jatko-oppikirja, family structure is described through possession. Both families are identified by the husband-Markku Lahtinen and Pentti Nieminen. Their wives are then each respectively introduced as 'his wife' ('hänen vaimonsa') (Silfverberg, 2005:21). Markku's wife, who works for her husband's business, is named. In comparison, Pentti's wife, who holds a job completely separate from her husband's, remains unnamed. While this could be due to an attempt to avoid the monotony of describing each couple the exact same way, this does construct an 
unequal understanding of gender. Each woman belongs to her husband and is allowed one individual trait, either her name or her job. In comparison, men have names, wives, jobs and families and are treated as the representative of their family unit.

The Suomen kielen jatko-oppikirja contains four biographies of famous Finnish authors-three texts and one dialogue. All four are men. A similar phenomenon has been noted in a number of studies of English language texts. The studies propose that this could paint an unequal picture to students, but could also be historically accurate (Holmqvist and Gjörup, 2007: 25). However, an interesting feature of these specific biographies is the representation of the men's wives. Of the four men, Johan Vilhelm Snellman, Eino Leino, and Elias Lönnrot all had wives and families, which are not mentioned in the textbook. Less importantly, while Aleksis Kivi did have relationships, those are not mentioned either. By only spotlighting Finnish male writers without their families, the book constructs a history of Finland based on literary achievement which excludes women.

\section{Conclusion: Inclusions and Exclusions}

In terms of substantive content, the textbook constructions of Finland and Finnishness conform to popular images of the country and its people. Alexander Stubb, one time Prime Minister of Finland, has been an avid advocate of 'country branding'. His popular writings in the Finnair in-flight magazine, as well as the final report of the Country Branding Commission, initiated by the then foreign minister Stubb (Maabrändivaltuuskunta, 2010), extol 'lakes, trees, Santa Claus, world-class education, Nokia, Formula 1 drivers, design, snow, sauna [and] the land of the midnight sun' as particularly Finnish virtues (Stubb, 2009: 102). Other, more abstract characteristics, such as social 
equality in general and gender equality in particular are also featured. But as we argued in the beginning, the substantive content is only one aspect of our analysis. Rather we have been more interested in what is being done with the discursive constructions, that is, how particular identity discourses enable or constrain an inclusive understanding of Finnishness.

In texts whose function is to socialise people into a language and a culture, questions of inclusion and exclusion are paramount. Hence from a critical discourse analysis perspective, what is not said becomes as important as what is (Fairclough, 1989: 84). From this perspective, the modern, advanced and nature-loving Finns look somewhat different. They are, first of all, very middle class. Every adult in the material either works or studies. Some differences between income and cultural capital, if you will, are exhibited in Suomen kielen jatko-oppikirja. But at the same time these are brushed aside by concluding that the neighbouring families 'get on well' despite their differing economic status (Silfverberg, 2005: 21). While undoubtedly a truthful portrayal of many real-life situations, the absence of poor people and depictions of class difference also reinforces the culture of consensus (AUTHORS BLINDED), where the recognition of social hierarchy is blurred. While it could be argued that this is not an issue for professional migrants or university students in other countries, the case is not the same with poor immigrants and refugees. Representing people's social worth through their work is an ideological construction.

Second, overall, Finland, the Finns, and even the characters from other countries depicted in the material are overwhelmingly white. There is Pedro, the mixed-race Brazilian, and Diego, who we can only surmise from the name to be Hispanic. More importantly, all of the Finns portrayed in the texts are white. While demographically the vast majority of Finns are indeed white, urban Finland is slowly but surely starting to look more multicultural. In terms of inclusivity, the material shows a glaring 
indifference to-or ignorance of-this fact. Again, this is a theme that is highly pertinent especially for language learners in Finland hoping to integrate into Finnish society and culture.

Finally, we looked at constructions of Finnishness through the lens of gender. As argued above, this is particularly relevant for Finland and the other Nordic countries that have for a long time prided themselves on gender equality. From our analysis, however, it is difficult to see Finland as any sort of gender utopia. Instead, gender roles are rather conventional-not only in the substantive representations of men and women, but also in how agency is discursively constructed, that is, who gets to speak and what they say when they speak. The maternalism-construction of women's primary national role through reproduction and family-rearing-discussed by Anttonen (1998:359363) and Vickers (2006: 96-97; see Yuval-Davis 1997:22), is very much present in the textbooks. There are independent women (especially younger, non-married women) in the narrative, but it seems that there is not only a discrepancy between the rhetoric of equality and its implementation (Holli, Magnusson \& Rönnblom 2005), but that conventional ('maternal') discourses linger alongside more progressive ones. The often repeated discourse of incommensurable gender cultures as points of friction between allegedly progressive Finns and allegedly patriarchal refugees from the Middle East is complicated when socialisation through adult language learning materials is considered. Interestingly, social and cultural change in the last 25 years does not show in the older pair of textbooks. The latest editions exhibit the same conventional, conservative characteristics. Dovetailing with the traditional gender roles is an unquestioned heteronormativity (cf. Gray, 2013b).

In summary, Finnish language adult learner textbooks construct a rather exclusive view of Finnish culture as middle-class, white and conservative in terms of gender relations and sexuality. This has obvious implications for creating a sense of inclusiveness - that is, what the discourse does, as 
emphasised above. There are, however, two potential counterarguments against our interpretation of these implications, one practical, one theoretical. First, it could be argued that textbooks are 'designed to meet the practical necessities of teaching rather than to give an accurate portrayal of the target culture' (Johnson; 1973: 47-48), and hence our argument is superfluous. This, however, only makes sense if we take a very narrow view of the language learner. As we quoted Pavlenko and Latoff above: learners are always 'concrete socially constituted and always situated beings' (2000: 155). On the one hand, new immigrants are eager to learn the host language in order to understand the culture they observe around them, and hence absorb all cues regarding that culture from the textbooks. On the other hand, university students in other countries are eager to learn not just the language but the culture which they cannot observe directly. Sometimes-although nowadays less so, thanks to electronic communication-language students are completely dependent on the 'cultural capital' absorbed from textbooks.

Second, and more importantly, it could be argued that we cannot know the effects of the constructions of Finnishness from the texts themselves. This is a valid argument, and in order to avoid committing this kind of fallacy of internalism (Hjelm, 2014: 94-5), we do not assume that every learner reads the texts as critically as we do. However, we do argue that textbook discourse constructs different 'worlds of possibility', and that particular constructions enable or constrain inclusive interpretations of Finnishness. The effects of seeing Finns as white and middle-class may be subtle, but they are real. How do non-white and unemployed immigrants situate themselves in Finnish society and culture if what they learn excludes them from full membership? Although there is no direct causality from construction to action, we argue that the 'worlds of possibility' constructed in the textbooks constitute 'adequate causality' in the Weberian sense; for more strict evaluation of the effects of textbook discourse we need further reception research, whether surveys or ethnographies. 
Language learning has often been seen as a way to build social capital and as a vehicle for integration in the host society-certainly from the host society's perspective. Looking at the Finnishness constructed in Finnish language adult learner textbooks, the 'worlds of possibility' come out rather thin. Integration - which, ideally, includes adaptation from both immigrants and the host society-shrivels down into assimilation, where the changes demanded of the newcomers far outweigh those demanded of the host society' (Allen, 2006: 251; see Cheong et al., 2007). An inclusive Finnishness, however, could take heed from the conclusions of a Canadian study: 'hostlanguage learning researchers and educators should focus on language not as something we obtain in order to gain membership in a given community, but as something we learn and use partly as a result of being included in a particular community' (Allen, 2006: 262). This seems particularly pertinent in times of heightened awareness of national identity. Although, as our analysis shows, they are not quite there yet, Finnish language textbooks could be not just vehicles for integration through language, but inclusive invitations to membership in Finnish culture.

\section{Endnote}

[1] While we acknowledge that a systematic analysis of images would be an interesting addition to the analysis of normative constructions of Finnishness, it is unfortunately beyond the scope of this article. We have, however, referred to accompanying illustrations when relevant to the understanding of the text.

\section{References}

Alcoff L M (2003) Introduction: Identities: Moder and Postmodern. In: Alcoff L M and Mendieta E (eds) Identities: Race, Class, Gender, and Nationality. Oxford: Blackwell Publishing, pp. 1-8.

Allen, D (2006) Who's in and who's out? Language and the integration of new immigrant youth in Quebec. International Journal of Inclusive Education 10(2-3): 251-263. 
Anttila J (2007) Kansallinen identiteetti ja suomalaiseksi samaistuminen. Helsinki: Helsingin yliopiston sosiaalipsykologian laitos.

Anttonen A (1998) Vocabularies of Citizenship and Gender: Finland. Critical Social Policy 18(3): 355373.

Bénéï V (2005) Introduction: Manufacturing citizenship: confronting public spheres and education in contemporary worlds. In: Bénéï' V (ed) Manufacturing Citizenship: Education and nationalism in Europe, South Asia and China. London: Routledge, pp. 1-34.

Bénéï' V (2008) Schooling Passions: Nation, History, and Language in Contemporary Western India. Standford, California: Standford University Press.

Berger, PL and Luckmann T (1967) The Social Construction of Reality: A Treatise in the Sociology of Knowledge. Garden City, NY: Anchor Books.

Bourdieu P and Passeron J-C (1990[1970]) Reproduction in Education, Society and Culture. Second edition. London: Sage

Brubaker R and Cooper F (2000) Beyond 'Identity'. Theory and Society 29(1): 1-47.

Cheong PH, Edwards R, Goulbourne H and Solomos J (2007) Immigration, Social Cohesion and Social Capital: A Critical Review. Critical Social Policy 27(1): 24-49.

Curdt-Christiansen XL and Weninger C (2015a) Introduction: Ideology and the politics of language textbooks. In: Curdt-Christiansen XL and Weninger C (2015) Language, Ideology and Education: The Politics of Textbooks in Language Education. London: Routledge, pp. 1-8.

Curdt-Christiansen XL and Weninger C (2015b) Language, Ideology and Education: The Politics of Textbooks in Language Education. London: Routledge. 
De Cillia R, Reisigl M, Wodak R (1999) The Discursive Construction of National Identities. Discourse \& Society 10(2): 149-173.

Erikson KT (1966) The Wayward Puritans: A Study in the Sociology of Deviance. New York: John Wiley and Sons.

Fairclough N (1989) Language and Power. London: Longman

Fairclough N (1992) Discourse and Social Change. Cambridge: Polity Press.

Fleming, D 2010 Becoming Citizens: Racialized Conceptions of ESL Learners and the Canadian Language Benchmarks. Canadian Journal of Education 33(3), 588-616.

Gehring S and Heinzmann S (2013a) Suomen mestari 1. Helsinki: Finn Lectura.

Gehring S and Heinzmann S (2013b) Suomen mestari 2. Helsinki: Finn Lectura.

Gehring S, Heinzmann S, Päivärinne S and Udd T (2013) Suomen mestari 3. Helsinki: Finn Lectura.

Giroux HA and Penna AN (1979) Social Education in the Classroom: The Dynamics of the Hidden Curriculum. Theory \& Research in Social Education 7(1), 21-42.

Gray, J (2013a) Critical Perspectives on Language Teaching Materials. Basingstoke: Palgrave Macmillan.

Gray, J (2013b) LGTB invisibility and heteronormativity ELT materials. In Gray, J (ed) Critical Perspectives on Language Teaching Materials. Basingstoke: Palgrave Macmillan, pp. 40-63.

Hjelm T (2014) Social Constructionisms: Approaches to the Study of the Human World. Basingstoke: Palgrave Macmillan. 
Holli A, Magnusson E \& Rönnblom M (2005) Critical Studies of Nordic Discourses on Gender and Gender Equality. NORA - Nordic Journal of Feminist and Gender Research 13(3), 148-152.

Holmqvist P and Gjörup L (2007) The Representation of Gender and Gender Roles in English Textbooks. Thesis. Malmö University.

Honko L (1996) Changing National Identities: Finland 1996. Anthropological Journal of European Cultures 5(2), 35-63.

Jasinski J (2001) Sourcebook on Rhetoric: Key Concepts in Contemporary Rhetorical Studies. Thousand Oaks, CA: Sage.

Johnson J (1973) Stereotypes in English Textbooks of German. Zeitschrift für Kulturaustausch 23: 4754.

Jones M, Kitetu C and Sunderland J (1997) Discourse Roles, Gender and Language Textbook Dialogues: Who learns what from John and Sally? Gender and Education 9(4): 469-490.

Kauppi N (1996) The Finns, Unusual People of the North: Race, Theories and National Identity in Finland. The American Historical Review 101(2), pp. 509-510.

Keskinen S (2015) Limits to Speech? The Racialised Politics of Gendered Violence in Denmark and Finland. Journal of Intercultural Studies 33(3): 261-274.

Kramsch C (1993) Context and Culture in Language Teaching. Oxford: Oxford University Press.

Lepäsmaa A and Silfverberg L (2010) Suomen Kielen Alkeisoppikirja. 12th ed. Helsinki: Finn Lectura.

Maabrändivaltuuskunta (2010) Tehtävä Suomelle! Maabrändiraportti 25.10.2010. Helsinki: Maabrändivaltuuskunta. 
Marakowitz E (1996) Gender and National Identity in Finland: An Exploration into Women's Political Agency. Women's Studies International Forum 19 (1/2): 55-63.

Mole R (ed.) (2007a) The Discursive Construction of Identity in European Politics. Basingstoke: Palgrave Macmillan.

Mole R (2007b) Discursive Identities/Identity Discourses and Political Power. In Mole R (ed.) The Discursive Construction of Identity in European Politics. Basingstoke: Palgrave Macmillan, pp. 1-21.

Moran M (2015) Identity and Capitalism. London: Sage.

Näre L and Nordberg C (2016) Neoliberal Postcolonialism in the Media: Constructing Filipino Nurse Subjects in Finland. European Journal of Cultural Studies 19(1): 16-32.

Nikander P (2008) Constructionism and Discourse Analysis. In Holstein JA \& Gubrium JF (eds) Handbook of Constructionist Research. New York: The Guilford Press, pp. 413-428.

Olbertz-Siitonen M and Siitonen M (2015) The Silence of the Finns: Exploring the Anatomy of an Academic Myth. Sosiologia 52(4), pp. 318-333.

Opetushallitus (2011)

http://www.oph.fi/download/135734 Kommentoitu luettelo maahanmuuttajataustaisten opetuks en ja koulutuksen materiaaleista 2011.pdf (Accessed 18 January 2017)

Paasi A (1997) Geographical Perspectives on Finnish National Identity. GeoJournal 43(1): pp. 41-50.

Pavlenko A and Lantolf JP (2000) Second Language Learning as Participation and the (Re)construction of Selves. In Lantolf JP (ed.) Sociocultural Theory and Second Language Learning. Oxford: Oxford University Press, pp. 155-177. 
Poole R (2003) National Identity and Citizenship. In: Alcoff L M and Mendieta E (eds) Identities: Race, Class, Gender, and Nationality. Oxford: Blackwell Publishing, pp. 271-280.

Richardson JE (2007) Analysing Newspapers: An Approach from Critical Discourse Analysis. Basingstoke: Palgrave.

Risager K and Chapelle C A (2012) Culture in Textbook Analysis and Evaluation. The Encyclopedia of Applied Linguistics.

Salmu, A (2002) Nais- ja mieskuva Suomi toisena kielenä -oppikirjoissa. Pro gradu -työ. Jyväskylän yliopisto, kielten laitos, suomen kieli.

Sercu L (1998) Learning Culture from Foreign Language Textbooks: Reality or Illusion? The Case of Flemish Adolescent Pupils Learning German. Internationale Schulbuchforschung 20(3): 275-293.

Silfverberg L (2003) Suomen Kielen Jatko-oppikirja. 6th ed. Helsinki: Finn Lectura.

Soysal YN and Schissler H (2005) Introduction: Teaching Beyond the National Narrative. In: Schissler $\mathrm{H}$ and Soysal YN (eds) The Nation Europe and the World: Textbooks and Curricula in Transition. New York and Oxford: Berghahn Books, pp. 1-9.

Stubb A (2009) The Naked Truth and Other Stories about Finns and Europeans. Helsinki: WSOY.

Tanner, J (2012) Rakenne, tilanne ja kohteliaisuus. Pyynnöt S2 -oppikirjoissa ja autenttisissa keskusteluissa. Suomen kielen, suomalais-ugrilaisten ja pohjoismaisten kielten ja kirjallisuuksien laitos. Helsingin yliopisto. Helsinki: Helsingin yliopisto.

Ulrich N (2004) Towards a Methodology for Analysing the Cultural Content of Modern Foreign Language Textbooks. Internationale Schulbuchforschung 26(2): 165-179. 
Vehkanen, M (2015) Kieliopista kommunikaatioon: Suomi toisena ja vieraana kielenä -oppikirjat vuosina 1866-1953. University of Helsinki, Faculty of Arts, Department of Finnish, Finno-Ugrian and Scandinavian Studies.

Vickers J (2006) Bringing Nations In: Some Methodological and Conceptual Issues in Connecting Feminisms with Nationhood and Nationalisms. International Feminist Journal of Politics 8(1): 84-109.

Virdee S, Kyriakides C and Modood T (2006) Codes of Cultural Belonging: Racialised National Identities in a Multi-Ethnic Scottish Neighbourhood. Sociological Research Online 11(4). Available at: http://www.socresonline.org.uk/11/4/virdee.html

Wodak R and Boukala S (2015) European Identities and the Revival of Nationalism in the European Union: A Discourse Historical Approach. Journal of Language and Politics 14(1): 87-109.

Yuval-Davis N (1997) Gender and Nation. Thousand Oaks, CA: Sage. 